\title{
The Property Law in Countries in Transition, Taking Albania of after ' 90 Years as Reference
}

\author{
Arjan Qafa \\ Candidate to Doctor in Law \\ European University of Tirana, Albania \\ arjan.qafa@hotmail.com
}

\section{Doi:10.5901/mjss.2014.v5n3p204}

Abstract

One of the characteristics that the researchers of the counties in post-communist transition address to these counties is the transformation of the property's form from the model of national property into model constituting on the combination of public property with that private. The most part of the effects of this transition are even the variations into legal framework accompanying this process, as well as juridical conception of the property's law. From the studies carried out it is noted that the transition doesn't have the same impact and outcomes in these post-communist countries by the point of view of property's law. Some countries have passed a fastest and smooth transition; meantime some others have passed, or are jet under through a difficult and problematic transition. The studies reached the conclusion that the property's law has suffered variations, but these changes are frequently problematic for each post-communist country, not-reflecting the same shapes observed on other post-communist countries in transition, and the concept and current practices related to the property's law in Albania remain jet opened to be improved, and bringing them in conformity with standards of European law. The matter remaining opened to the debate is, so, that of identifying the factors which have contributed in that field and the distinguishing among them for the countries in transition and the property's law in post-communist countries. This research tends to treat changes on property's law in the context of the transition of Albanian society. It intends to identify which have been the variations regarding to the property's law, if those changes are the same or different from those happened in other postcommunist countries in transition, and how the happened changes comply with historical and modern concept of the property's law. The examination of these changes is expanded into a period of 20 years (1990-2010) focusing in legal framework of the property's law.

Keywords: Propriety Law, Legal Amendments, Legal Framework, Transition, Albania

\section{What Makes Its Study so Interesting}

\subsection{Two Elements on practical direction distinguished}

First, the Property's Law suffers a significant change from the conception and communist application (abnormal) towards a new conception and liberal implementation (normal) of property's law (Damsa 2009). In communist system, the property's law (Verdery 2003):

1. doesn't be cancelled from the books, but was restricted and unified with personal goods;

2. was more an administrative issue than a legal one;

3. is tightly linked with owners' identity and reflects the relationships among them;

4. reflects 4 property's forms (public, cooperativist, personal, and private);

5. is realized throughout the hierarchy and delegation from the Party (Bregma\& Lawrence 1990);

6. the administrators gains the management's right but not that of the ownership (Dunn 2002);

The communist concept on the property's law led on the creation of (Verdery 2003):

1. a system of multiplied and overlapped property's law;

2. managers class deciding related to the circulation but not being its owners;

Second the transformation of the Property's Law is related to:

1. transformation of socialist proprietor relations (Frydman\&Rapaczynski 1994);

2. transformation of the concept and values towards the property (Heller \& Serkin 1999, Vedery 2003);

3. practices of restitution, distribution, justification (Edmondson 2009);

4. moral dimension of restitution and distribution (Damsa 2009); 
5. impact over people of ownership's ways (Riha 1996, Berend 2009).

\subsection{Two Elements are distinguishedon theoretical direction}

First, The transformation's explanation through Property's classic Theory. This explanation:

1. is problematic because of the classic theories treat the utilization, exclusion, and transformation practices, but not those of restitution and property's distribution (Damsa 2009). The use of liberal concept justice-property-law can explain transforming dynamics and practices of the restitution and property's distribution even though the utilization will be approached to the specifications of the post-communist context.

\section{The Theories on the Property's Law}

\subsection{Classic Legal Theory}

This theory treats the Justice on different the points of view (Vallentyne 2007)

1. as distributing matter of profits and losses - incomes, social structures, legal systems;

2. as legitimacy matter - not-intervention of others;

3. as proportional fairness matter - profiting equally despite what is normally right or deserved;

4. as fairness matter - giving everybody what belongs to them;

5. as a matter of moral obligation towards each-other - respecting of the rights of any individual.

2.2 The theory links the Property's Law with justice's forms

1. formal justice - formalism and consistent implementation of the procedures (Weber 1978, Hart 1997, Hooker 1999);

2. substantial justice - clarification of the rights people have to require from one-other and from the Government (Damsa 2009);

3. procedural justice-impartially implementation of legal rules and treatment of everybody in an equal manner (Bell 2009, Solum 2009);

4. retributive justice - fairness distribution of resources (Aristotle);

5. commutative justice - fairness in wages, prices and exchanges (Fleischacker 2004);

\subsection{Anglo-American classic theory on property}

This theory treats the property by 3 points of view of practices and normal development (Damsa 2009):

1. as utilization matter;

2. as transferring matter

3. links the Property's Law with the following aspects (Damsa 2009):

1. with labor (Locke 1690) - the property's right is generated by the labor; by the mixing of labor with other means not having in ownership before;

2. with benefit (Bentham 1789) - the property's right comes out by the marginal benefit of a thing;

3. with human nature (Hume 1972) - the property's right comes out from relative lack of things, human nature for possessing;

4. with individual will (Kant 1965) - the property's right comes out by the reasoning, will, being first possessor, and universal law of freedom;

5. with the individual's personality (Hegel 1965) - the property's right comes out from the conscience and will of individual to invest himself and his labor into different things;

6. with moral development (Green 1911) - the property's right comes out the necessity of the individual to fully realize his potential;

7. with land (Munzer) - the property's right comes out by the work as a social activity;

8. with efficiency (Demsetz 1967) - the property's right comes out from the fact that the private ownership makes more efficient distribution of recourses than any other method;

9. with freedom (Nozik 1974) - the property's right comes out from the negative freedoms, the right to not-facing 
mandatory interventions by others versus the thing he possesses.

\section{What Theoretical Point-of-View Fits to the Property's Study in Legalist Theory?}

\subsection{Legalist theory of transition's law}

This theory treats the dynamics and differences with Property's right from following points-of-view (Damsa 2009):

1. as a concerting matter (Damsa 2009)

2. as a law-making matter (Bell 2009, Teitel 2009)

3. as a law matter (Sartor 2009, Freedman 2009)

4. as a justifying matter (Damsa 2009)

This theorylinks the dynamics and differences with Property's right with following aspects (Damsa 2009):

1. property's restitution (retributive law);

2. property distribution/privatization (distributive law)

3. property's compensation (retributive law) It offers a model evaluating variations on the Property's Law over 6 elements:

1. the conception before variation

2. used instruments;

3. process's features;

4. observed practices;

5. factors \& influencing conditions;

6. observed effects.

Referring to judicial terms, we will examine the ownership's law in Albania of post ' 90 years, coinciding with transition's period.The proprieties' issue, from an almost inexistent status of private property during the communist regime, after the big transformation of 1990 for the restoration of the democratic system, was significantly affected.

\subsection{The Property's law in Albania is examined throughout 4 laws \& 4 elements}

- Law no. 7501 dated 19 July 1991 On the land; Law no. 7652 dated 23 December 1993 On the homes; Law no. 7698 dated 15 April 1993 On properties' compensation; Law no. 9235 dated 29 July 2004 On properties' restitution/compensation.

- 1) type of justice; 2) ownership's modality; 3) Used instruments; 4) Experiences.

\subsubsection{Element of model}

What is observed in Albanian post-communist transition's dynamics referring to the property's law?

As law-making type.Distributive law (fair distribution).Law no. 7501 (1991) On the land, Article 2; Article 3, Article 3a, Article 6, Article 25. The land is conferred in inheritance:

1. to the natural and legal persons;

2. domestic or alien;

3. in village.Law no. 7652 (1993) On the houses, Article 3, The houses are given for free to:

4. houses constructed before 1970;

\subsection{Restributive law (mistakes' remedy, damage indemnify)}

Law no. 7652 (1993) On houses, Article 7, Article 7/a, Article 8, Article 15, Article 17, the houses are conferred as compensation and remuneration to:

1. ex political homeless persecuted;

2. homes constructed after natural disaster, in falling risk, requiring remedies;

3. the flooded by hydro-power stations;

4. the displaced by force;

5. the homeless people to whom hose was destructed due to arranging plans or public interest.Law no. 7698 (1993) On restitution and properties' compensation, Article 5, Article 16, define the criteria and conditions of 
compensation to ex-owners for:

1. lands;

2. grounds;

3. objects/premises. Law no. 9235 (2004) On restitution and properties' compensation, Article 11, Article 14, recognizes to the ex-owners the right of compensation through:

1. other public immovable properties,

2. lands in touristic areas;

3. shares on companies with state capital;

4. value of the premises announced for privatization

5. the right of first refusal

\section{As Ownership's Modalities}

\subsection{The assignment(of the right)}

- Law 7501 (1991) On the land, Article 3, the land is given in ownership/possession without remuneration;

- Law no. 7652 (1993) On the homes, Article 1; The homes are given to the tenants throughput their privatization;

- Law no. 7698 (1993) On restitution and properties' compensation, Article 17, Article 20, Article 21, recognizes to the ex-owners the right:

1. on grounds where premises or dwelling-houses were constructed throughout converting of ex-owners in co-owners with premise and house owner;

2. on ground occupied by state premises (shops, warehouses, factories) throughout of their right of first refusal from the state to ex-owner;

3. on state buildings in rate 1:2 for one-floor buildings, 1:3 for two-floor buildings.Law no. 9235 (2004) On restitution and properties' compensation, Article 1 , Article 2, Article 6, recognizes to the ex-owners the ownership right on properties:

1. expropriated, nationalized, confiscated or seized by the state from 29 November 1944 throughout the restitution or compensation with special law;

2. upto 100 ha

\subsection{The restitution (right's recognizing)}

- Law no. 7698 (1993) On restitution and properties' compensation, Article 1, Article 2, Article 4, Article 7, Article 8, Article 9, Article 10, Article 11, Article 13, Article 15, Article 18, Article 19, recognizes to the ex-owners the ownership's right on properties:

1. nationalized, expropriated, confiscated after 29 November 1944;

2. immovable properties in the form of ground (not agricultural land), dwelling houses, factories, shops, facilities, warehouses;

3. upto 100 ha

4. agricultural land up to $5000 \mathrm{~m} 2$;

5. unoccupied grounds, expropriated by recompense when the owner gives back the taken recompense;

6. grounds occupied after 1990 with dwelling-houses, premises, after paying back by the state of the purchasing price;

7. grounds occupied with temporary constructions;

8. free grounds within urban borders of towns and touristic areas, according to the urban arranging plans up to $5000 \mathrm{~m} 2$;

9. different buildings/premises, not-demolished, not-utilized for public goals, not-compensated when are expropriated;

10. buildings/premises purchased by the state not-having ex-owners' consent, and the latter are ready to pay back the recompense taken on the expropriation's time;

11. buildings/premises alienated by thirds and don't exist permanent premises on this property, after restitution being paid back by the State to third party; 
12. buildings/premises on which the state has carried out certain investments, but without indemnify for investments when these constitute $20 \%$ of the object's value;and with paying by the ex-owner of the investment's amount if these are between 20-50\%;

13. premisesillegally privatized, privatized properties without activity during 6 last months.Law no. 9235 (2004) On restitution and properties' compensation, Article 6, Article 8, Article 10, recognizes to the exowners the ownership right on:

1. properties and lands expropriated within touristic areas as per Law no. 7665 On development of touristic areas (21 January 1993); in possession of the Ministry of Defense; agricultural lands in possession of researching-scientific institutions; lands flooded by the hydroelectric power stations;

2. lands in possession of companies and this last refuses to pay the price of land as per market price;

3. terrains assigned to thirds persons, without permanent and legal facilities, after the compensation of third persons by the State;

4. private terrains occupied with permanent legal facilities in ownership of the State when the premises don't be used for public interest, and ex-owner is ready to exercise its right of first refusal related to the premise's purchase; when it is rented out to third parties;

5. properties expropriated for public interest but don't be used anymore for that goal.

\subsection{The compensation (of the right)}

- Law 7501 (1991) on Land, Article 19, compensates natural or legal persons as ex-owners to whom property:

1. is using for public interests. Law no. 7698 (1993) On restitution and properties' compensation, Article 5, Article 16, compensates ex-owners for terrains:

1. $100 \%$ to terrains up to $10.000 \mathrm{~m} 2,+10 \%$ terrains up to $100.000 \mathrm{~m} 2,+1 \%$ terrains over $100.000 \mathrm{~m} 2$;

2. having permanent premises up to $5000 \mathrm{~m} 2$ (with state obligations, equivalent terrain surfaces, terrains in touristic areas);Law no. 9235 (2004) On restitution and properties' compensation, Article 6, Article 7, Article 9, recognizes the compensation to ex-owners:

1. for part of not-restituted/not compensated property;

2. with immovable properties for public utilization intended for assignment;

3. for properties with facilities illegally constructed but in via of legalization;

\subsection{Exclusion (by the right)}

- Law 7501 (1991), On Land, Article 19, Article 21, there are excluded by the ownership right the natural/legal persons when dealing with:

1. utilization of private property for public interests;

2. propertyoccupation in an illegal manner. Law 7652 (1993), On Houses, Article 10, Article 11, Article 12, Article 18, Article 21, Article 21/a, Article 23, Article 23/a, excludes by the ownership right when dealing with:

1. terrain in co-ownership;

2. dwelling surface excessive and over allowed rates;

3. individuals who doesn't desire to purchase the property by pay the rent;

4. state building ex private property remaining in the administration of Housing Entity, and those built after 1990 and on;

5. property's pretention over 2 state houses;

6. peasants who have profited residence permit into cities after 1991;

7. thecivics who have rent emigrants' houses.Law no. 7698 (1993) On restitution and properties' compensation, Article 2, Article 3, Article 6, Article 11, Article 12, Article 13, Article 18, Article 23, Article 24, excludes by the ownership's right the ex-owners of:

1. agricultural lands, out yellow line of urban centers at the moment of expropriation;

2. facilities and terrains expropriated for public interests recompensed with full expropriation's price;

3. premises willfully donated to the State by ex-owner;

4. properties that were part of urban arrangement plans and on which the civics have constructed homes according to legal procedures; 
5. premises with investments by the State over $50 \%$ of object's value (ex-owner becomes co-owner with the State);

6. privatized premises in an illegal way, properties privatized but not having an activity during 6 last months;

7. royal properties and properties of alien/common companies;

8. those who have collaborated with nazi-fascistoccupier, ex-leaders of the party and communist regime, and the condemned for property's appropriation;Law no. 9235 (2004) On restitution and properties' compensation, Article 4, Article 6, Article 7, , excludes the restitution/compensation of ownership's right to:

1. individuals who have profited by the Agrarian Reform (Law 108, 29 August 1945), by the Law 7501 On the Land (19 July 1991); are expropriated for public interests and are compensated; have willfully donated their properties to the State

2. agricultural lands;

3. expropriations for public interests to which the compensation is made;

4. properties with public interest; that serve the realization of Albanian State obligations; that are occupied with legal acts; that are related to the planned urban and economical developments and investments.

\section{As Instruments Used for the Distribution of Socialist Property}

There are two legal instruments used:

- Law 7501, 19 July 1991, On the Land;

- Law 7652, 23 December 1993, On the Houses;

\subsection{For property's restitution to ex-owners}

There are two legal instruments used:

- Law 7698, 15 April 1993, On properties' compensation;

- Law 9235, 29 July 2004, On properties' restitution/compensation

\subsection{As observed experiences}

For laws and instruments. Variations and frequent amendments:

- Law 7501, On the Land, 5 times amended;

- Law 7652, On Houses, 4 times amended;

- Law 7698, On properties' restitution/compensation, 12 times amended;

\subsection{For privatization/restitution/compensation policies}

- privatization in phases, politicized in character, preferential in treatment;

- restitutions and property's compensations in a selective manner.

As above mentioned, the ownership right appears important in the context of society's transition in Albania as well as in other post-communist countries; but it is unfolded accompanied by different realitieshappened into countries, where in each country are reflected different realities which will be subject of a later work. In the case of Albanian transition, the ownership right appears followed by three phenomena: social relationship characterized by conflict and self-judgment, trial decisions being in counterpart with the observance of the ownership's right, which in many cases have impacted that our State be punished with fines by the Court of Strasbourg, also there are noted unstable dynamics on real estates market due to problems with property's rights. One of the effects of this transition is also the variation on the legal framework accompanying this process, as well as juridical riconception of the Property's Law. 


\section{References}

(Demsetz 1967) "Toward a Theory of Property."

Dunn 2002); Rural Business Service Kooperativa, Raporto Kooperativa Informacion, agricultural cooperatives.

(Berend 2009 \& Riha 1996). Ownership and publications for author Riha 1996, and 2009 for the author Berend.

Frydman, R. \& Rapaczynski, A. (1994) Privatization in Eastern Europe the role of the state:

K.Verdery 2003, Vanishing Hectare: Property and Value in Postsocialist Transylvania.

Munzer 1990, A Theory of Property, Gain labor theory of property.

Nozik 1974, for further protection of the right of slavery.

Hart 1997 Incomplete Contracts and Public Ownership.

( Teitel 2009) transitional justice, and comparative constitutional law 